\title{
19
}

\section{Cut-verbs of the Oceanic} language Teop: A critical study of collecting and analysing data in a language documentation project

\author{
Ulrike Mosel
}

\section{Introduction}

Teop is an Oceanic language spoken in Bougainville, Papua New Guinea, and has been documented for more than two decades in close collaboration with a team of native speakers from coastal villages of the Tinputz region. ${ }^{1}$ The present study of Teop cut-verbs was inspired by Anna Wierzbicka when she invited me to a workshop on endangered meanings held in Canberra in 2013. Having been a tutor for her courses in the '90s, I soon realised that the English translation equivalents of Teop cuT-verbs in the Teop Language Corpus do not provide sufficient information for a semantic analysis, because the translators (including myself) have been 'imprisoned in English' (Wierzbicka 2014). To understand the meanings of cut-verbs, we therefore need to complement the corpus data by

1 The Teop language documentation has been funded by the Australian Research Council in 1994, the Volkswagen Stiftung 2000-07, the Deutsche Forschungsgemeinschaft 2007-11 and the private sponsor Annemarie Dahlhaus 2011-14. 
observing what people are doing when cutting things, document what we see by videos or photographs and ask native speakers for explanations in their language.

The following sections start with a brief description of the compilation and content of the Teop Language Corpus in section 2. In section 3 I discuss my method of collecting the data for the analysis of CUT-verbs and present a list of all CUT-verbs that are analysed in section 4. This analysis shows that by syntactic and semantic criteria two general and 17 specific CUT-verbs can be distinguished, none of which correspond to English types of CuT-verbs. The last section contains a summary and some thoughts about the compilation of dictionaries of endangered languages.

\section{The Teop Language Corpus}

The Teop Language Corpus (Mosel et al. 2007) is compiled in ELAN, and currently consists of approximately 250,000 words. ELAN ${ }^{2}$ is a software tool that facilitates time-aligned transcriptions and further annotations such as translations on separate tiers. In ELAN, annotated corpora can be searched simultaneously on several tiers by using the query language regular expressions (see Friedl 2006; Mosel 2015, 2018: 260-61).

The corpus contains folk tales, personal histories, procedural texts of house building, canoe building, fishing and cooking, and descriptions of plants and animals. All texts are translated into English. We distinguish between three types of texts: (1) transcriptions of audio recordings, (2) edited versions of the transcriptions done by native speakers and (3) texts written by native speakers without previous recordings. The edited and written texts were checked by indigenous teachers who wanted to use them in school. In the abbreviations of the references for the examples given below these three text types are distinguished by R, E and W. In addition to these texts, the corpus contains collections of example sentences that were written by native speakers on the basis of Teop word lists.

2 ELAN is available through the Max Planck Institute for Psycholinguistics, The Language Archive, Nijmegen, The Netherlands. Available at: archive.mpi.nl/tla/elan. 


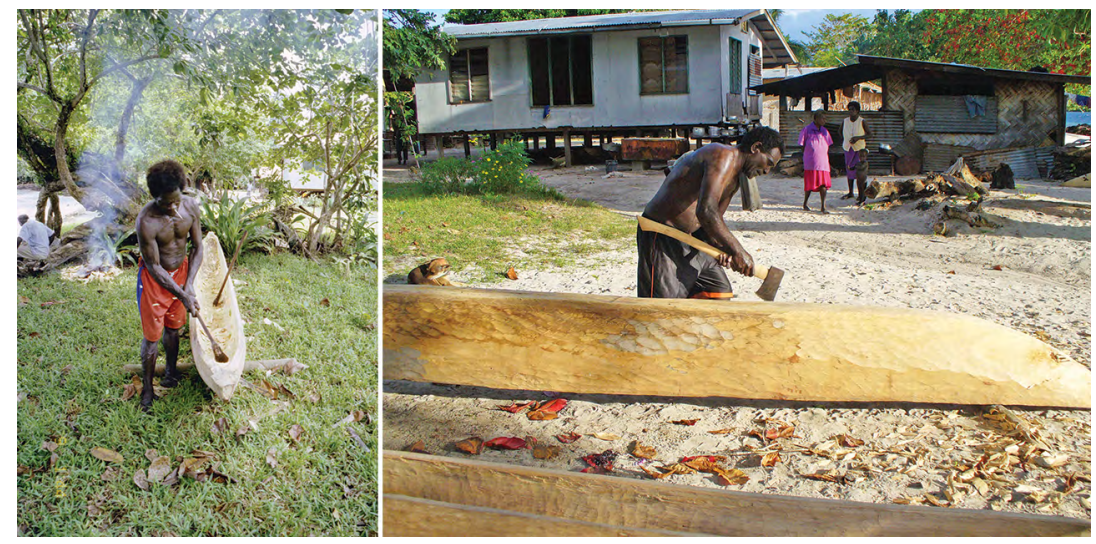

Figure 19.1. Koro 'carve the inside of a canoe'; taraha 'carve the outside of a canoe'.

Source: Photograph by the author.

For the documentation of the material culture we often took photographs, which were used as illustrations of previously produced texts or as stimuli for eliciting new texts. For example, I watched the butchering of a chicken and of a pig and took a series of photographs that depict every single activity of these complex events. Later the photographs were used for the elicitation of texts (Mosel 2014: 148-49). To get further examples of cutting events I simply observed people, asked them what they were doing, and if they didn't mind, took photographs (Figure 19.1).

In contrast to Majid et al. (2007), I never used video clips or pictures made outside the fieldwork site for elicitation or elicited data by asking for translations from English or Tok Pisin into Teop (see Mosel 2012: 81-82), but a weakness of our corpus is that it lacks data giving negative evidence (cf. Hellwig 2010: 817-19, 824).

\section{Data mining}

I started my investigation of CUT-verbs by searching the corpus for the English word forms cut, cuts, cutting on the free translation tier (f) and their aligned Teop counterparts on the transcription tier $(t)$. The former were searched for by the regular expression <cut(ting)?s? >, the latter by the so-called wild card $<. *^{*}$. This first search found 18 different Teop words. Then, each of the 18 Teop words was searched for on the transcription tier to find more translation equivalents on the translation tier. 
The search for taraha, for instance, not only found Teop utterances in which taraha was translated by 'cut', but also utterances with the translation equivalents 'carve' and 'shave'. When I then searched for carve and shave, I did not only find the expected word taraha, but also the word kamuru 'shave'.

Table 19.1 shows all cuT-verbs of the present study, including reduplicated forms, the number of tokens, meaning descriptions and the referents of the objects. The referents of the subjects are not included, because only the subject of the verb pee 'cut' occasionally occurs with a non-human subject referring (e.g.) to the thing that cuts.

$\begin{array}{llllll}\text { (1) erau ta } & \text { kehaa } & \text { pee } & \text { vai } & \text { bona } \\ \text { so poce } & \text { shell } & \text { cut } & \text { now } & \text { 4sG.Pron } \\ \text { '(and) so a piece of shell cut her,' (Pur 05R 105) } & \end{array}$

Table 19.1. Teop cut-verbs.

\begin{tabular}{|c|c|c|c|}
\hline Teop verb & Tokens & $\begin{array}{l}\text { Meaning descriptions } \\
\text { with translation equivalents } \\
\text { in brackets }\end{array}$ & $\begin{array}{l}\text { Referents of the object } \\
\text { in the corpus }\end{array}$ \\
\hline $\begin{array}{l}\text { govara, } \\
\text { govagovara }\end{array}$ & 38 & $\begin{array}{l}\text { 1) 'cut the head off a person } \\
\text { or animal' ('behead') } \\
\text { 2) 'cut a person's or animal's } \\
\text { head off } \\
\text { 3) 'cut the pointed ends } \\
\text { of a canoe' ('carve') }\end{array}$ & $\begin{array}{l}\text { 1) person; animal } \\
\text { 2) head } \\
\text { 3) canoe }\end{array}$ \\
\hline $\begin{array}{l}\text { hape, } \\
\text { hapehape }\end{array}$ & 3 & 'cut off a protruding part' & branch, fin of a shark \\
\hline $\begin{array}{l}\text { kaku, } \\
\text { kaakaku }\end{array}$ & 27 & $\begin{array}{l}\text { 'cut an animal into pieces' } \\
\text { ('butcher') }\end{array}$ & pig, chicken, turtle, fish \\
\hline kamuru & 3 & 'shave a person's head' & person \\
\hline $\begin{array}{l}\text { kaporo, } \\
\text { kapokaporo }\end{array}$ & 28 & $\begin{array}{l}\text { 1) 'cut something with } \\
\text { scissors' } \\
\text { 2) 'cut a person's hair with } \\
\text { scissors' }\end{array}$ & $\begin{array}{l}\text { 1) hair, dress } \\
\text { 2) person }\end{array}$ \\
\hline $\begin{array}{l}\text { kepo, } \\
\text { kepokepo }\end{array}$ & 35 & $\begin{array}{l}\text { 1) 'cut a log into the shape of } \\
\text { something' ('carve') } \\
\text { 2) 'cut up (a log)' ('chop') }\end{array}$ & $\begin{array}{l}\text { 1) canoe } \\
\text { 2) stem of a tree or palm }\end{array}$ \\
\hline $\begin{array}{l}\text { kopaa, } \\
\text { kopakopaa }\end{array}$ & 69 & $\begin{array}{l}\text { 1) 'cut something lengthwise' } \\
\text { 2) 'cut something from top } \\
\text { to bottom' }\end{array}$ & $\begin{array}{l}\text { 1) chicken, pig, stem of } \\
\text { a palm, bamboo; strap } \\
\text { 2) papaya; watermelon }\end{array}$ \\
\hline
\end{tabular}




\begin{tabular}{|c|c|c|c|}
\hline Teop verb & Tokens & $\begin{array}{l}\text { Meaning descriptions } \\
\text { with translation equivalents } \\
\text { in brackets }\end{array}$ & $\begin{array}{l}\text { Referents of the object } \\
\text { in the corpus }\end{array}$ \\
\hline koro & 37 & $\begin{array}{l}\text { 1) 'cut something out' } \\
\text { ('carve out') } \\
\text { 2) 'cut the inside of something } \\
\text { out' }\end{array}$ & $\begin{array}{l}\text { 1) canoe, stem of a sago } \\
\text { palm } \\
\text { 2) inside of something }\end{array}$ \\
\hline $\begin{array}{l}\text { kosi, } \\
\text { kookosi }\end{array}$ & 28 & $\begin{array}{l}\text { 1) 'cut leaves off a tree, branch } \\
\text { or frond' } \\
\text { 2) 'cut off the leaves' }\end{array}$ & $\begin{array}{l}\text { 1) branch, sago palm, } \\
\text { banana plant, pandanus } \\
\text { 2) leaves }\end{array}$ \\
\hline $\begin{array}{l}\text { kurusu, } \\
\text { kurukurusu }\end{array}$ & 63 & $\begin{array}{l}\text { 1) 'cut off something long' } \\
\text { 2) 'cut off a part of } \\
\text { something long' }\end{array}$ & $\begin{array}{l}\text { 1) vines, string, } \\
\text { dreadlocks } \\
\text { 2) head of a pig, crown of } \\
\text { a tree, bananas hanging } \\
\text { from their stalk }\end{array}$ \\
\hline $\begin{array}{l}\text { mosi, } \\
\text { mosimosi }\end{array}$ & 217 & $\begin{array}{l}\text { 'cut something with any kind } \\
\text { of tool except scissors' }\end{array}$ & all kinds of things \\
\hline реe, реepee & 66 & $\begin{array}{l}\text { use a small knife or shell and } \\
\text { 1) 'make a cut into something' } \\
\text { 2) 'cut a part off a whole' } \\
\text { 3) 'cut something into pieces' }\end{array}$ & $\begin{array}{l}\text { 1) body part } \\
\text { 2) body part } \\
\text { 3) chicken, cake }\end{array}$ \\
\hline poana & 10 & $\begin{array}{l}\text { 'cut the upper part off a log } \\
\text { resting horizontally when } \\
\text { building a canoe' ('slice') }\end{array}$ & canoe \\
\hline papaesi & 6 & $\begin{array}{l}\text { 'cut the sides of a canoe into } \\
\text { shape' ('chop') }\end{array}$ & canoe \\
\hline potaa & 16 & 'cut something open' & $\begin{array}{l}\text { chicken, pig, } \\
\text { bêche-de-mer }\end{array}$ \\
\hline rapisi & 4 & $\begin{array}{l}\text { 'cut something with a bush } \\
\text { knife' }\end{array}$ & grass, belly of pig \\
\hline $\begin{array}{l}\text { rom, } \\
\text { romrom }\end{array}$ & 34 & $\begin{array}{l}\text { 'cut something long crosswise } \\
\text { into pieces' ('slice') }\end{array}$ & $\begin{array}{l}\text { trunk of a pig, body of } \\
\text { a person, stem of a tree, } \\
\text { eggplant, greens }\end{array}$ \\
\hline tagava & 44 & 'cut a tree' ('fell') & tree, palm \\
\hline $\begin{array}{l}\text { taraha, } \\
\text { tarataraha }\end{array}$ & 46 & $\begin{array}{l}\text { 1) 'cut little parts off a wooden } \\
\text { thing to make its surface } \\
\text { smooth' ('chop, shave') } \\
\text { 2) 'cut something off ('chop') }\end{array}$ & $\begin{array}{l}\text { 1) canoe, knots of } \\
\text { bamboo; pestle; } \\
\text { mortar; planting stick } \\
\text { 2) bark }\end{array}$ \\
\hline Total & 774 & & \\
\hline
\end{tabular}

Source: Author's summary, based on Teop Language Corpus.

All CUT-words and multiword expressions containing CUT-words are documented with examples and pictures in A Multifunctional Teop-English Dictionary (Mosel 2019). When you search the semantic domain for cutting, you find 89 entries with examples and illustrations. 


\section{The meaning of cut-words}

\subsection{Introduction}

In accordance with my search methods, the term 'Teop cuT-verbs' does not denote a Teop semantic domain. Before we have analysed the data, we don't know if there is anything other than the translation equivalents that justifies grouping the words together (see Haviland (2006: 153) on 'carry' verbs in Chinese and Tsoltil). My analysis is largely based on Goddard and Wierzbicka's $(2009,2016)$ parameters of the lexicosyntactic frame, the effect the cutting event has on the object, the instrument and the manner of using the instrument, but for reasons of space and time it does not employ the Natural Semantic Metalanguage. With respect to the corpusbased analysis of CUT-words and their collocations and constructions my approach is influenced by Hanks' work $(2012,2013)$.

In the following I distinguish between 17 specific and 2 general CuTverbs. Since the most obvious formal characteristic of the two general CuT-verbs is that they can be modified by specific cuT-verbs in serial verb constructions, the specific CUT-verbs are analysed before the general ones.

In view of these considerations, this chapter is structured as follows: I will first describe the valency patterns of cuT-verbs with a focus on verbs that encode cutting events that separate a part from its whole. In section 4.3, I identify several semantic characteristics that distinguish specific from general CUT-verbs, and then analyse the semantics of two specific CUTverbs in section 4.4 and of the two general cut-verbs in section 4.5 and section 4.6, and the origin of two modern cuT-verbs in section 4.7.

\subsection{Valency patterns of Teop cut-verbs}

All Teop cut-verbs are transitive verbs. Their subjects prototypically denote the person doing the action and the objects the person, animal or thing that is affected by the cutting event. With respect to their valency patterns, the verbs denoting events in which a part is cut off its whole form a special group. The object may either refer to the part that is cut off or to the whole that loses the part, which suggests that the kind of part that is cut off is implied in the meaning of the verb or the context. 
In the following example the verb kosi 'cut leaves' is used in the second type of construction in (2a) and in the first one in (2d). Note that the serial verb construction mosi hapehape 'cut off branches' in (2c) also represents the second type of construction.

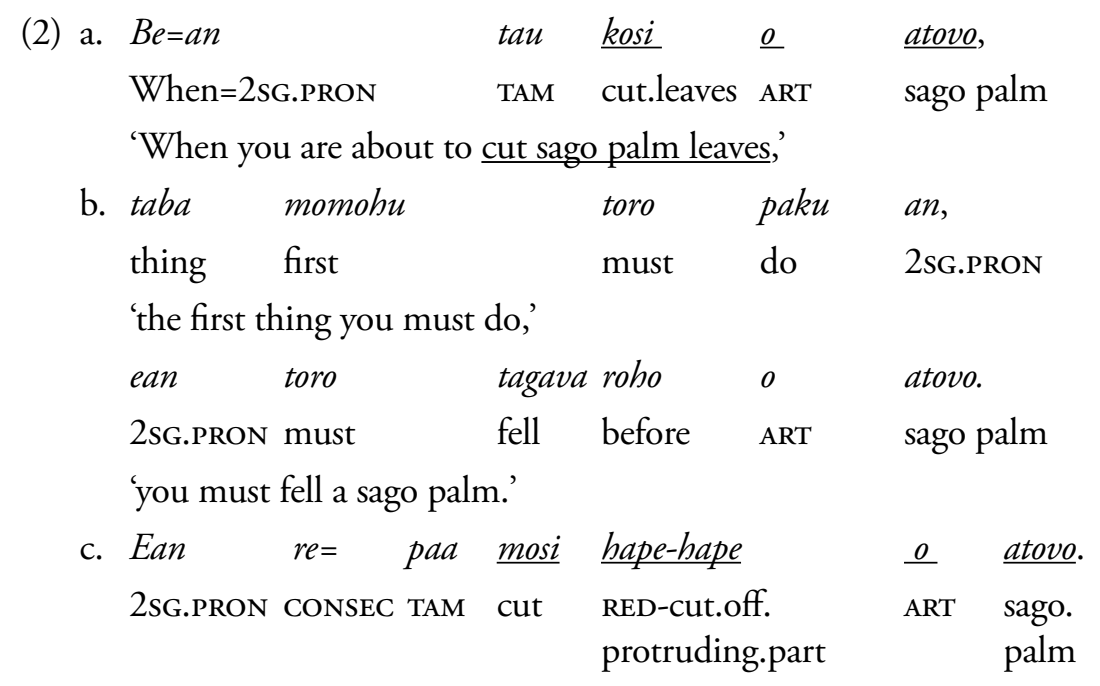

'Then you cut off the branches of the sago palm.'

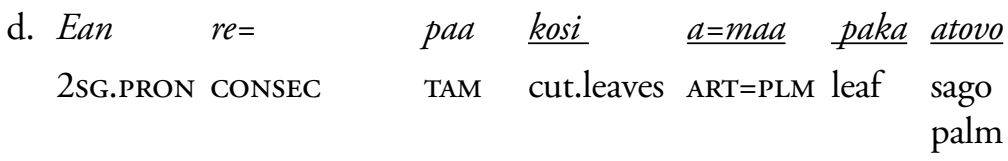

'Then you cut the sago palm leaves'

kahi bono sinoo vaa tobina.

off ART bone LNK middle

'off the midrib.' (Sii Joy 03W 007-009)

Table 19.2 lists all verbs that are attested in both construction types, the verb kaporo 'cut with scissors' will be discussed in section 4.3. 
Table 19.2. cut-verbs with two kinds of object referents.

\begin{tabular}{|l|l|l|l|}
\hline Teop verb & Meaning descriptions & $\begin{array}{l}\text { 1) Object referent: } \\
\text { the whole }\end{array}$ & $\begin{array}{l}\text { 2) Object referent: } \\
\text { the part }\end{array}$ \\
\hline govara & $\begin{array}{l}\text { 'cut off a person's or } \\
\text { an animal's head' }\end{array}$ & person; animal & head \\
\hline hape & $\begin{array}{l}\text { 'cut off a protruding } \\
\text { part' }\end{array}$ & palm & $\begin{array}{l}\text { branch, fin of } \\
\text { a shark }\end{array}$ \\
\hline kaporo & $\begin{array}{l}\text { 'cut something with } \\
\text { scissors' }\end{array}$ & $\begin{array}{l}\text { person } \\
\text { dress or skirt }\end{array}$ & $\begin{array}{l}\text { hair } \\
-\end{array}$ \\
\hline kosi & $\begin{array}{l}\text { 'cut the leaves off } \\
\text { something' }\end{array}$ & tree, palm, branch & leaves \\
\hline koro & $\begin{array}{l}\text { 'cut out the inside of } \\
\text { something' }\end{array}$ & log, canoe & $\begin{array}{l}\text { the inside of } \\
\text { something }\end{array}$ \\
\hline taraha & 'shave something off & log & bark \\
\hline
\end{tabular}

Source: Author's summary, based on Teop Language Corpus.

\subsection{The meaning of cut-verbs in context}

As illustrated by the examples (3) and (4) and summarised in Table 19.3, most cutting events encoded by the specific cuT-verbs and their constructions can be distinguished by one or more of the following characteristics:

1. a certain part that is cut off a whole; for example kosi 'cut leaves' (2), koro 'cut out the inside of a $\log$, a canoe, a mortar' (3d)

2. the fact that something is cut off and removed from its original place; for example tagava 'cut, fell a tree' (2b, 3a, 3b)

3. the fact that something is cut into pieces (4)

4. the instrument used for the cutting; for example kaporo 'cut with scissors' (4)

5. the movement of the cutting instrument in relation to the dimensions of the thing that is cut $(3 b, 3 c)$.

The citation (3) comes from a description of the sago palm, whereas (4) is said by a teacher of needlework in a personal oral narrative. 
(3) a. $\mathrm{Na}$

$$
\begin{array}{lllll}
\text { antee } & r a= & \text { ara } & \text { tea } & \text { tagava, } \\
\text { can } & \text { IPL. } & \text { IPL. COMPL } & \text { fell } \\
& \text { IN.IPFV }= & \text { IN.PRON }
\end{array}
$$

'We can fell (it),'

o atovo mee o manoto.

ART sago.palm also ART ready to be harvested
'the sago palm is also ready to be harvested.'
b. Tagava vai ori, o=re paa rom bari. fell now 3PL. 3PL. TAM3 cut.crosswise 4PL. PRON, PRON=CONSEC PRON

'They fell (it), and then they cut it crosswise into pieces.'

$\begin{array}{lllll}\text { c. } O=\text { re } & \text { pad } & \text { kopad } & \text { pete } & \text { bari. } \\ \text { 3pl.pron=consec } & \text { tam3 } & \text { cut. } & \text { in.addition } & \text { 4PL. } \\ & & \text { lengthwise } & & \text { PRON }\end{array}$

'Then they cut them (the pieces) lengthwise.'

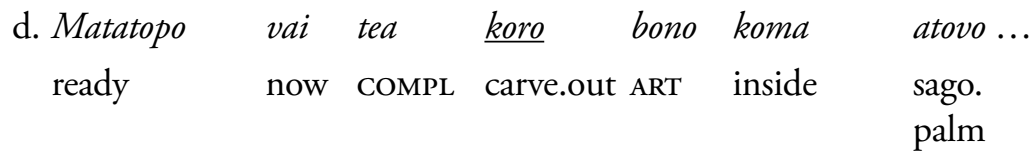

'Now (the people) are ready to carve out the inside of the sago palm ...'

(Sii 17W 124-126)

(4) a. be $=$ naa kaporo bata nom

when $=1$ sG.PRON cut.with. for.a.while ISG.IPFV scissors

'(You keep watching) while I am cutting (the cloth for)'

$\begin{array}{clllll}\text { b.o } & \text { koros } & \text { te=an } & \text { ge } & \text { sikioti } & t e=a n . \\ \text { ART } & \text { dress } & \text { PREP=2SG. } & \text { or } & \text { skirt } & \begin{array}{l}\text { PREP=2SG. } \\ \text { PRON }\end{array} \\ & & & & \text { PRON }\end{array}$

'your dress or your skirt (into size).' (Nan 01R 099) 
Table 19.3. Types of cutting events.

\begin{tabular}{|c|c|c|}
\hline Cutting events & Verbs & $\begin{array}{l}\text { Meanings of the verbs and their } \\
\text { contexts }\end{array}$ \\
\hline \multirow{9}{*}{$\begin{array}{l}\text { Cut-off-a-part-from-its- } \\
\text { whole }\end{array}$} & govara & 'cut off a person's or an animal's head' \\
\hline & hape & $\begin{array}{l}\text { 'cut off a protruding part (branch } \\
\text { of a tree, the fin of a shark)' }\end{array}$ \\
\hline & kamuru & 'shave a person's head' \\
\hline & kaporo & 'cut a person's hair with scissors' \\
\hline & koro & $\begin{array}{l}\text { 'cut out the inside of a log, a canoe, } \\
\text { a mortar' }\end{array}$ \\
\hline & kosi & $\begin{array}{l}\text { 'cut off the leaves of a tree, palm, } \\
\text { branch or frond' }\end{array}$ \\
\hline & kurusu & $\begin{array}{l}\text { 1) 'cut off something long' (e.g. an } \\
\text { animal's tail) } \\
\text { 2) 'cut off a part of something long' } \\
\text { (e.g. the head of a pig, the crown of } \\
\text { a felled tree) }\end{array}$ \\
\hline & poana & 'cut off the upper part of a log' \\
\hline & taraha & $\begin{array}{l}\text { 'cut little parts off the surface of a } \\
\text { wooden thing to make it smooth' }\end{array}$ \\
\hline \multirow[t]{2}{*}{$\begin{array}{l}\text { Cut-off-something- } \\
\text { from-its-place }\end{array}$} & kurusu & $\begin{array}{l}\text { 'cut off something long' (e.g. vines } \\
\text { in the jungle) }\end{array}$ \\
\hline & tagava & 'cut a tree' ('fell') \\
\hline \multirow[t]{5}{*}{$\begin{array}{l}\text { Cut-something-into- } \\
\text { pieces }\end{array}$} & $k a k u$ & $\begin{array}{l}\text { 'cut an animal into many different } \\
\text { parts' }\end{array}$ \\
\hline & kaporo & $\begin{array}{l}\text { 'cut something into pieces with } \\
\text { scissors' (4) }\end{array}$ \\
\hline & kepo & $\begin{array}{l}\text { 'cut up a log; cut a log into the shape } \\
\text { of something' }\end{array}$ \\
\hline & kopaa & $\begin{array}{l}\text { 'cut something lengthwise or from the } \\
\text { top to the bottom' (see } \$ 4.4 \text { ) }\end{array}$ \\
\hline & rom & $\begin{array}{l}\text { 'cut something crosswise into pieces' } \\
(\$ 4.4)\end{array}$ \\
\hline \multirow{2}{*}{$\begin{array}{l}\text { Cut-something-by-a- } \\
\text { specified-movement } \\
\text { of the instrument }\end{array}$} & kopaa & $\begin{array}{l}\text { 'cut something lengthwise or from top } \\
\text { to bottom' }(\$ 4.4)\end{array}$ \\
\hline & rom & 'cut something crosswise’ (see $\$ 4.4$ ) \\
\hline \multirow{2}{*}{$\begin{array}{l}\text { Cut-something-with-a- } \\
\text { specific-instrument }\end{array}$} & kaporo & 'cut something with scissors' (4-6) \\
\hline & rapisi & 'cut something with a bush knife' \\
\hline
\end{tabular}

Source: Author's summary, based on Teop Language Corpus. 
In Table 19.3, the specific cuT-verbs are sorted according to the five characteristics of cutting events listed above. Due to the interaction of the meaning of CUT-verbs and the meaning of their contexts, several verbs are listed in more than one field of the types of cutting events. A typical verb that can be used for the encoding of distinct cutting events is kaporo 'cut something with scissors'. While the construction of kaporo in (4) belongs to the type Cut-something-into-pieces, the construction of kaporo in (5) belongs to the type Cut-off-a-part-from-its-whole.

\begin{tabular}{|c|c|c|c|c|c|}
\hline$b e=a n$ & kaporo & nom & $a$ & vипии & $n a=e$ \\
\hline $\begin{array}{l}\text { when=2sG. } \\
\text { PRON }\end{array}$ & $\begin{array}{l}\text { cut.with. } \\
\text { scissors }\end{array}$ & 2SG.IPFV & ART & hair & $\begin{array}{l}\text { 3SG.POSS = 3SG. } \\
\text { PRON }\end{array}$ \\
\hline
\end{tabular}

'when you cut his hair' (Sia 01E(Joy) 120)

In (5) the part, vиnuu 'hair', and the whole, nae 'his', are explicitly mentioned, but hair-cutting events can also be encoded by clauses in which the object of kaporo 'cut with scissors' does not refer to the hair, but to the person who gets a haircut as in (6).
(6) Meve
paa
kaporo
bene
Sookara.
And.3SG.Pron
TAM
cut.with.scissors
ART Sookara
'And she gave Sookara a haircut.' (Sia 01E(Joy) 123) ${ }^{3}$

In (6) vипии 'hair' is not mentioned but nevertheless the clause refers to a hair-cutting event and does not mean 'she cut Sookara with scissors'. Since all 14 occurrences of kaporo with an object referring to a person mean that this person gets his or her hair cut with scissors, this construction can be regarded as a conventional phraseological pattern (Hanks 2012: 75, 2013: 95).

\subsection{Cutting lengthwise and crosswise}

The meanings of the two verbs kopaa 'cut something lengthwise or from top to bottom' and rom 'cut something crosswise' are not evident from their original translations in texts, because both verbs are simply translated by 'cut' or 'cut up'. Occasionally kopaa is translated by 'cut open' and rom by 'slice'.

3 Note that (5) and (6) refer to the same event in a personal narrative. 


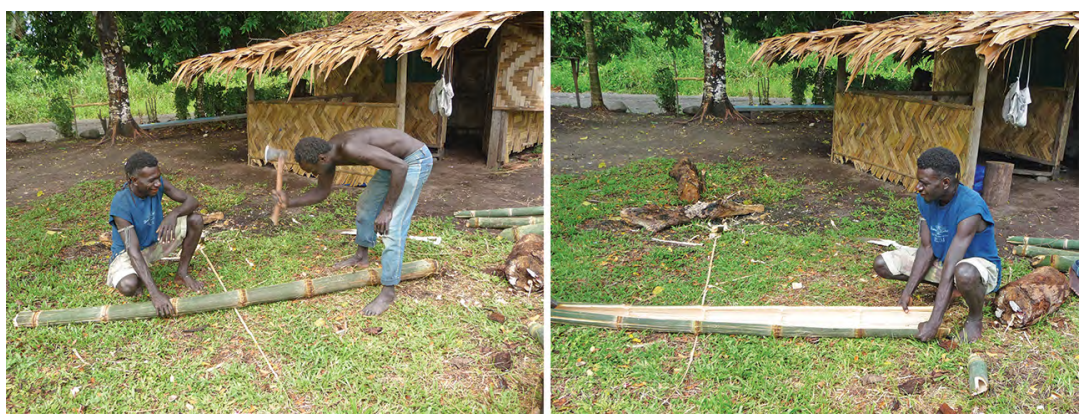

Figure 19.2. Kopaa 'cut something lengthwise'.

Source: Photograph by the author.

That the two essential distinctive semantic features of kopaa and rom are 'lengthwise or from top to bottom' and 'crosswise', respectively, only became obvious to me when I observed cutting events and asked native speakers what they were doing.

The objects of rom and kopaa typically refer to long things like a bamboo or the trunk of a pig (Figure 19.2). But I also heard people using the verb kopaa when they showed me how they cut up citrus fruit and watermelons. In this case, the cut starts at the stalk and runs down to the bottom (Figure 19.3), while rom denotes a crosswise cut (Figure 19.4). These observations and the native speakers' comments led me to the hypothesis that the distinctive feature between kopaa and rom is the movement of the cutting instrument in relation to the dimensional properties of the thing that is cut, though only very few of the original translations reflect this semantic characteristic.

Furthermore, with respect to the butchering of chickens and pigs, my interpretation is supported by the observation that in the context of butchering the cut called kopaa and translated by 'cut open' starts at the throat and runs down to the anus. Additional evidence is found in the descriptions of colourful fishes and the drawings by the Teop artist Neville Vitahi. Stripes that run from the head to the tail are called rahirahi kopaa 'horizontal stripes' and those that run crosswise rahirahi rom 'vertical stripes'. 


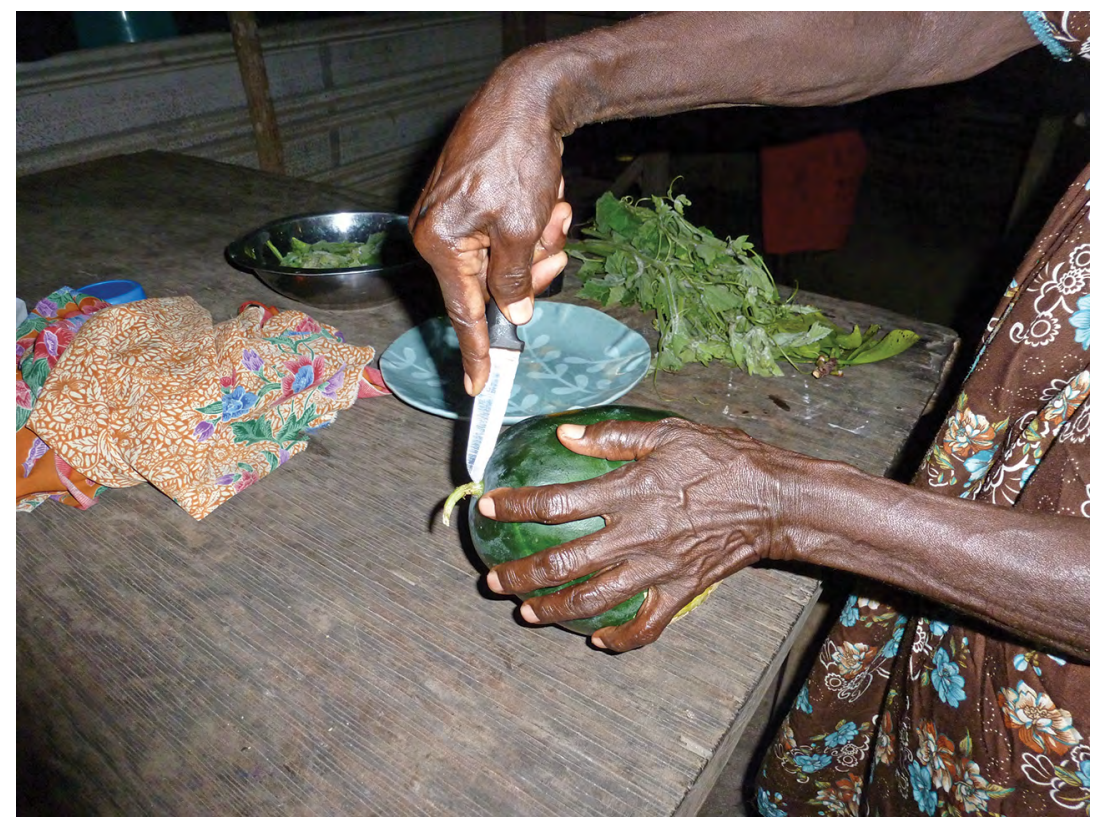

Figure 19.3. Kopaa 'cut from top to bottom'.

Source: Photograph by the author.

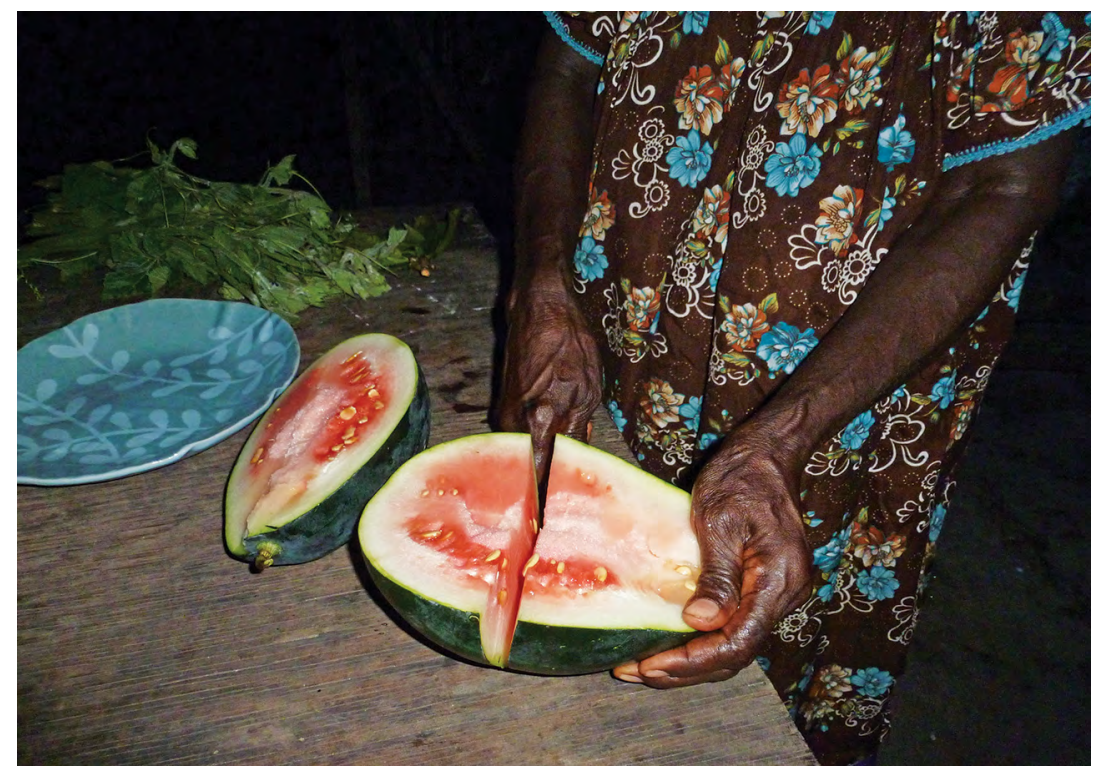

Figure 19.4. Rom 'cut crosswise'.

Source: Photograph by the author. 

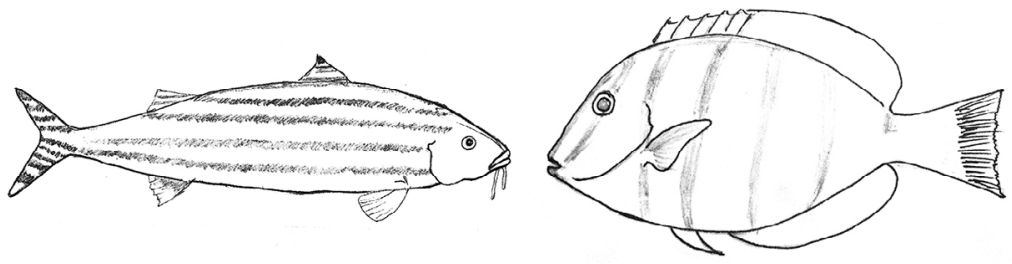

Figure 19.5. Riivivi (an unidentified fish), koinia 'Convict Surgeonfish'.

Source: Photograph by the author.

(7) $A$

ART iana

fish riirivi...,

riivivi

'The riirivi fish ...,'

evehee a sii rahirahi kopaa a rom na=e.

but ART DIM stripes lengthwise ART trunk 3sG.POss=3SG.

PRON

'but its trunk is a bit striped from the head to the tail.' (Sii $11 \mathrm{~W} 096$ )

(8)
koinia...
a rahirahi rom
paru ...

ART Convict Surgeonfish ... ART stripes crosswise black

'The Convict Surgeonfish ... has black vertical stripes ...'

(Vaa 09W 212)

Once I had discovered the essential semantic features 'crosswise' and 'lengthwise or from top to bottom', I started revising the translations. The following revised example illustrates how confusing the earlier version was that translated romrom simply by 'cut' and kopaa by 'cut open'.

(9) $B \boldsymbol{e}=a r a$

rom-rom

vakavara $e$,

When=1PL.IN

RED-cut.crosswise

finished 3sG.PRON

'When we have finished cutting it up crosswise,' (i.e. the palm stem)

eara re=paa paku pete a kiu vaa tea kopaa.

1PL. CONSEC=TAMdo also ART work LNK COMPL cut.

IN.PRON

lengthwise

'we also do the work of cutting lengthwise.'

Eara he toro kopaa $e \quad$ te $=0$ bum $\underline{\text { buaku. }}$.

IPL. but must cut.lengthwise 3SG.PRON PREP=ART piece two IN.PRON

'But we must cut them lengthwise into two pieces.' (Eno 04W 015) 
In other contexts, however, the translation of kopad by 'cut open' can make sense for the reader of the English translation, as in the examples (3c) and (10):

$\begin{array}{lllllll}\text { (10) Murinae } & \text { eara } & \text { resaa } & \text { pee } & \text { kopaa } & e & \text { guu. } \\ \text { after.that } & 1 \mathrm{PL} . & \text { CONSEC }= & \text { cut.with. } & \text { cut. } & \text { ART } & \text { pig } \\ & \text { IN.PRON } & \text { TAM } & \text { knife } & \text { lengthwise } & & \end{array}$

'After that we cut the pig open'. (Then we start pulling out the inside of the pig.)'

(Eno 10E(Eno) 028-029)

Events of cutting open a palm or an animal's belly are also expressed by potad 'cut something open', which in contrast to kopaa is not attested in any other contexts or with translation equivalents:

$\begin{array}{lllll}M e=\text { ori } & \text { paa } & \text { potaa } & \text { bene } & \text { guu, ... } \\ \text { And=3PL.PRON } & \text { TAM } & \text { cut.open } & \text { ART } & \text { pig }\end{array}$

'And they cut the pig open (and put the intestines on a raft).' (Aro 15R 110-112)

These data suggest that the translation 'open' is not a semantic component of the word kopaa, but results from the word's usage in particular contexts where a lengthwise cut has the effect that something is cut open.

In conclusion, the semantic analysis of words should not exclusively rely on translation equivalents, because the source and the target languages may differ in their selection of which specific features of events, things and properties they encode (cf. Hellwig 2010), so that subtle distinctive features of the source language may not surface in translation equivalents, and vice versa: translation equivalents may encode features that are absent in the words of the source language. While in Teop the meanings 'open' and 'into pieces' are not encoded in the verb kopaa, the meaning 'lengthwise or from top to bottom' is not encoded in English 'cut' (cf. the explications of 'cut' in Goddard and Wierzbicka 2009: 64, 2016: 224). 


\subsection{The general cut-verb mosi 'cut'}

The verb mosi 'cut' encodes various kinds of cutting events that are distinguished by specific cuT-verbs, which leads to the assumption that mosi can be classified as a general cuT-verb or even as a hypernym of several other cut-verbs. The actions denoted by mosi 'cut' can be carried out by knives and axes, but in contrast to English 'cut' not by scissors (see section 4.7).

There are three kinds of evidence for mosi being a general cuT-verb:

1. its high frequency (see Table 19.1)

2. its use in the very same context as specific cUT-verbs

3. its modification by specific cut-verbs in a serial verb construction.

The verb mosi 'cut' is used to refer to the same kind of cutting events as hape 'cut off a protruding part', koro 'cut the inside out', pee 'cut with a knife or shell' and tagava 'fell a tree'. For example, in the legend of the origin of the coconut, mosi 'cut' and pee 'cut with a knife or shell' occur in exactly the same kind of context:

(12) Ean

$$
\text { toro mosi a moo-naa,... }
$$

2sG.PRON must cut ART leg-1sG.PRON

'You must cut off my leg, (and then throw it to him).' (San 01R 042)

(13)

$\begin{array}{lllllll}\text { Me keara } & \text { teve } & \text { pad } & \text { pee } & \text { bona } & \text { moo-na=e } \\ \text { and brother } & \begin{array}{l}\text { PREP.3SG. } \\ \text { PRON }\end{array} & \text { TAM3 } 3 & \text { cut } & \text { ART } & \text { leg-3sG. } \\ & & & & \text { POSS=3SG.PRON }\end{array}$

'And his brother cut his leg (and threw (it) to the spirit).' (San 01R 047)

Mosi may also be used in a context where someone cuts into something.

(14) E sumeke paa mosi bona moo-na=e me=paa rerevasin. ART old.man TAM cut ART leg-3sG.POss= and=TAM bleed 3SG.PRON

'The old man cut his leg, and it bled.' (Jub 01W 031) 
The distinction between the events of Cutting-off-something and Cutting-into-something is not lexicalised or encoded by conventional phraseological patterns, but only understood from the individual contexts of the verb mosi 'cut'.

Similar to the pair of mosi 'cut' and pee 'cut with a knife or shell', the two verbs mosi 'cut' and koro 'cut out the inside' are found in the very same context.

$$
\begin{aligned}
& \text { (15) } \ldots \text { mosi bata bona koma-n=o sinivi. } \\
& \text {... cut for.a.while ART inside-3sG.POSS=ART canoe } \\
& \text { '(then it is finished,) (and they) cut the inside of the canoe.' } \\
& \text { (Tah 02R 087) }
\end{aligned}
$$
(16) ... a $=r e$ pad taneo tea koro a $\underline{\text { kom-a- } n=o}$ sinivi ... 1PL. TAM start COMPL carve ART inside-3SG. canoe IN $=$ CONSEC POSS $=$ ART
'... (and) we then start carving out the inside of the canoe, ...'
(Tah 02E(Eno).023)

The third kind of evidence, the modification of the verb mosi 'cut' by specific CUT-verbs in a serial verb construction suggests that the semantic features of these modifying verbs are not part of the meaning of mosi (see Table 19.4).

Table 19.4. Mosi and modifying serial verbs.

\begin{tabular}{|l|l|l|l|}
\hline Serial verbs & \multicolumn{2}{|l|}{ Meaning descriptions of mosi and serial verbs } & Examples \\
\hline mosi govara & cut & cut the head off & 22 \\
\hline $\begin{array}{l}\text { mosi hape } \\
\text { mosi hapehape }\end{array}$ & $\begin{array}{l}\text { cut } \\
\text { cut }\end{array}$ & $\begin{array}{l}\text { cut off a protruding part } \\
\text { cut off protruding parts }\end{array}$ & 17 \\
\hline mosi kopaa & cut & cut lengthwise \\
\hline mosi kurusu & cut & $\begin{array}{l}\text { cut off something from something } \\
\text { long } \\
\text { cut off something long }\end{array}$ & 18 \\
\hline $\begin{array}{l}\text { mosi rom } \\
\text { mosimosi rom }\end{array}$ & cut & $\begin{array}{l}\text { cut something crosswise } \\
\text { cut something into slices }\end{array}$ & $\begin{array}{l}\text { Sii 41W 051, } \\
\text { Jen 01R 073 }\end{array}$ \\
\hline
\end{tabular}

Source: Author's summary, based on Teop Language Corpus. 
(17)

$\begin{array}{llll}B e=a n \text { rake ta } & \text { mosi } & \text { hape } & \text { to peho peana,... } \\ \text { if=2sG. want COMPL cut } & \begin{array}{l}\text { cut.off. } \\ \text { protruding.part }\end{array} & \text { ART some branch } \\ \text { PRON } & & \end{array}$

'If you want to cut off a branch, ...' (Sii 41W 037)

(18) me=paa mosi kopaa bene toa te=o buaku o hum and=TAM cut cut. ART chicken PREP= two ART part lengthwise ART

'.. and he cut the chicken lengthwise into two parts.'

(Pau 01E 019)

(19) A otei paa mosi kurusu bono kakarusu ART man TAM cut cut.something.long ART claw

'The man is cutting off the claws'

moo- $n=e \quad$ toa.

leg-3sG.POSS =ART chicken

'from the chicken's legs.' (Joy 11W 018) ${ }^{4}$

Further evidence for the classification of mosi 'cut' as a general cuT-verb is provided by the following quotation from a text about canoe building in which the author speaks of various kinds of cuts.
(20) $M e=a n$ antee nom tea mosi a=maa kaku mosi and=2sG. can 2SG.IPFV COMPLI cut ART=PLM kind cut PRON

'And you can cut the kinds of cutting

$\begin{array}{lll}\text { tabae to paku } & \text { nom=an } \\ \text { what } \quad \text { REL do } & \text { 2sg.ipfv=2sg.pron } \\ \text { 'whatever (it is) that you (want to) } & \text { do' (Mor 04R 44-47) }\end{array}$

4 The text Joy $11 \mathrm{~W}$ are captions that Joyce Maion wrote for 54 photographs showing the butchering of a chicken, see also (22-24). 


\subsection{The cUt-verb pee 'cut with a knife or shell'}

Compared to mosi 'cut', the verb pee 'cut with a knife or shell' is a specific CUT-verb as it only denotes cutting events that are carried out with a small instrument.

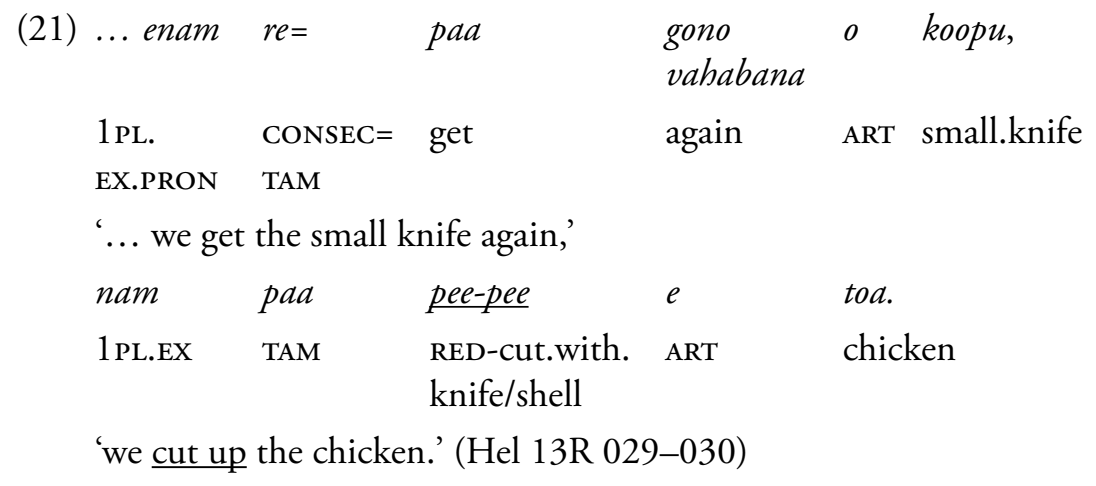

But similar to mosi 'cut', it may be modified by a specific cut-verb in a serial verb constructions $(10,22-23)$ and does not function itself as a modifying serial verb (see Table 19.5). Therefore I also classify it as a general cuT-verb.

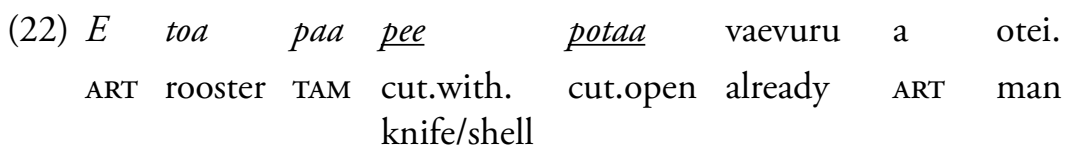

'The rooster has already been cut open by the man.' (Joy 11W 017)
(23) A otei na pee kopad nana bene toa ART man TAM cut.with. cut. 3SG.IPFV ART chicken knife/shell lengthwise

'The man is cutting the rooster'

$\begin{array}{lll}\text { te }=\mathrm{O} & \text { buaku } & \text { hum } \\ \text { PREP=ART } & \text { two } & \text { piece }\end{array}$


Table 19.5. Serial verb constructions headed by pee.

\begin{tabular}{|l|l|l|l|}
\hline Serial verbs & \multicolumn{2}{|l|}{ Meaning descriptions of mosi and serial verbs } & Example \\
\hline pee kopaa & cut with a knife/shell & cut something lengthwise & 10,24 \\
\hline pee kurusu & cut with a knife/shell & cut off something long & 23 \\
\hline pee potaa & cut with a knife/shell & cut something open & 22 \\
\hline
\end{tabular}

Source: Author's summary, based on Teop Language Corpus.

Depending on its context, pee 'cut with a knife or shell' may be interpreted as 'cut something into pieces' (21) or 'cut into something' (24). In the following example, the cut denoted by pee marks the place where later the head of the pig is cut off.

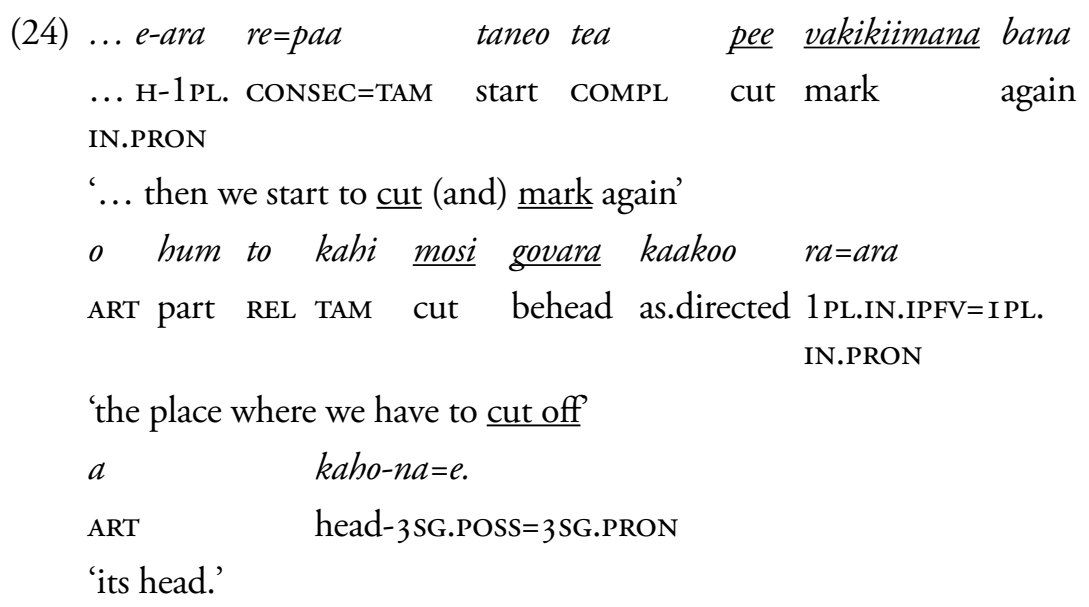

\subsection{Cut-verbs derived by semantic extensions}

There are two CUT-verbs that are derived by semantic extensions, namely kaporo 'cut with scissors' and rapisi 'cut grass; cut with a long bush knife'. The original meaning of the verb kaporo is 'remove the hot stones from the fire in the earth oven with tongs', but with the introduction of scissors the meaning was obviously extended to 'cut with scissors'. The word form kaporo is also a noun, meaning 'tongs' from which the noun kaporo 'scissors' is derived. The colexification' of tools and the actions done with tools is a common pattern in the Teop language. Scissors and tongs have similar shapes and also the movements of their two parts are similar.

5 The term colexification was coined by François (2008). 


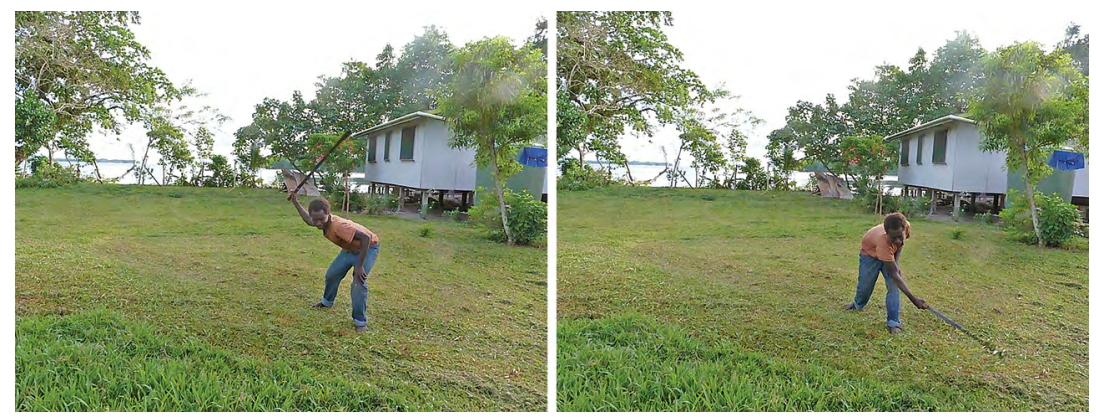

Figure 19.6. Rapisi 'cut with a bush knife'.

Source: Photograph by the author.

The verb rapisi 'cut with the bush knife' originally means 'whip'. Whipping and cutting, for example, the grass with a bush knife have in common that both activities are carried out by holding the stick or the knife in one hand, raising the arm behind one's head and swinging it down. This characteristic also explains why rapisi does not cover the meaning of mowing the grass with a mower.

\section{Summary and concluding remarks}

The Teop Language Corpus was systematically searched by three successive searches:

1. the search for 'cut' and its Teop counterparts

2. the search for the Teop words found in the first search (e.g. govara etc.), to find more English translation equivalents than 'cut' (e.g. 'behead')

3. the search for the new English translation equivalents to discover new Teop cut-words.

The corpus-based analysis and the observation of cutting events with subsequent explanations by native speakers show that in many aspects Teop cuT-verbs are significantly different from their English translation equivalents:

1. The verb mosi 'cut' is a general cut-verb. First, it is used within the same context as more specific cuT-verbs; second, it can be modified by specific CUT-verbs; and third, the action denoted by mosi 'cut' can be carried out by any kind of instrument with one sharp edge. The third characteristic explains why the word kaporo 'cut with scissors' 
was created when scissors were introduced into the Teop culture (see point 6, below). In contrast to the Teop word mosi, the English translation equivalent 'cut' includes the meaning 'cut with scissors' (see Goddard 2012: 713, 2015: 1692; Goddard and Wierzbicka 2016: $\left.224^{6}\right)$.

2. The number of distinct Teop cut-verbs-19-exceeds the number of their 7 English translation equivalents 'behead, butcher, carve, chop, fell, shave, slice'.

3. The specific cuT-verbs distinguish between:

1. different kinds of objects that are cut (section 4.3);

2. different placements of the cut in relation to the dimensional properties of the thing or animal that is cut (section 4.4);

3. different instruments (sections 4.6 and 4.7).

4. Although pee 'cut with a small knife or shell' is a specific CUTverb, it can also be considered as a general cuT-verb because like mosi 'cut' it can be modified by other specific cut-verbs (section 4.6).

5. Specific cut-verbs meaning 'cut a part off its whole' show two alternating valency patterns that denote the same kind of cutting event. The object of these verbs may either refer to a part of the whole or to the whole; that is, a thing, a person or an animal (section 4.2).

6. The verb-object constructions of the three verbs kopaa 'cut lengthwise or from top to bottom', mosi 'cut' and pee 'cut with a knife or a shell' do not distinguish between 'cut something into pieces' and 'cut into something. The effect of the cutting event can only be understood from the wider context.

7. The verbs kaporo 'cut with scissors' and rapisi 'cut something with a bush knife', which denote cutting events with recently imported instruments, are derived by semantic extensions from traditional action verbs. In both cases, the motivation for the semantic extension seems to be the movement of the cutting instrument.

The findings of our analysis suggest that lexicographers in language documentation projects should be aware of the fact that translation equivalents do not render the meanings of words and that the senses of words depend on their contexts. Consequently, if the dictionary is meant

6 In their explications of 'cut', Goddard and Wierzbicka give 'paper' as an example for the object of 'Someone is cutting something'. Since the cutting of paper is prototypically performed with scissors, their analysis of the English word 'cut' seems to include the cutting with scissors. 
to document the semantics of the lexicon rather than serving as a tool for rapid translations, the production of the dictionary requires timeconsuming semantic analyses (Haviland 2006; Mosel 2011). In any case, the dictionary entries should contain authentic translated examples that show the conventional use of the lemma (headword) and its different senses in context (Hanks 2013: 3-5; Mosel 2018: 262-63; Rehg 2018: 319-21).

\section{References}

François, Alexandre (2008). Semantic maps and the typology of colexification: Intertwining polysemous networks across languages. In Martine Vanhove (ed.), From Polysemy to Semantic Change. Amsterdam: John Benjamins, 163215. doi.org/10.1075/slcs.106.09fra.

Friedl, Jeffrey E.F. (2006). Mastering Regular Expressions. Beijing, Cambridge: O’Reilly.

Goddard, Cliff (2012). Semantic primes, semantic molecules, semantic templates: Key concepts in the NSM approach to lexical typology. Linguistics 50 (3): 711-43. doi.org/10.1515/ling-2012-0022.

Goddard, Cliff (2015). Verb classes and valency alternations (NSM approach), with special reference to English physical activity verbs. In Andrej Malchukov and Bernard Comrie (eds), Valency Classes in the World's Languages. Berlin: Walter de Gruyter, 1649-80. doi.org/10.1515/9783110429343-020.

Goddard, Cliff and Anna Wierzbicka (2009). Contrastive semantics of physical activity verbs: 'Cutting' and 'chopping' in English, Polish, and Japanese. Language Sciences 31: 60-96. doi.org/10.1016/j.langsci.2007.10.002.

Goddard, Cliff and Anna Wierzbicka (2016). Explicating the English lexicon of 'doing and happening'. Functions of Language 23 (2): 214-56. doi.org/ 10.1075/fol.23.2.03god.

Hanks, Patrick (2012). Corpus evidence and electronic lexicography. In Syviane Granger and Magali Paquot (eds), Electronic Lexicography. Oxford: Oxford University Press, 57-82. doi.org/10.1093/acprof:oso/ 9780199654864.003.0004.

Hanks, Patrick (2013). Lexical Analysis: Norms and Exploitations. Cambridge, MA: MIT Press. 
Haviland, John (2006). Documenting lexical knowledge. In Jost Gippert, Nikolaus P. Himmelmann and Ulrike Mosel (eds), Essentials of Language Documentation. Berlin, New York: Walter de Gruyter GmbH, 129-62.

Hellwig, Birgit (2010). Meaning and translation in linguistic fieldwork. Studies in Language 34 (4): 802-31.

Majid, Asifa, Melissa Bowerman, Miriam van Staden and James S. Boster (2007). The semantic categories of cutting and breaking events: A crosslinguistic perspective. Cognitive Linguistics 18 (2): 133-52. doi.org/10.1515/cog. 2007.005 .

Mosel, Ulrike (2011). Lexicography in endangered language communities. In Peter Austin and Julia Sallabank (eds), The Handbook of Endangered Languages. Cambridge: Cambridge University Press, 337-53. doi.org/ 10.1017/cbo9780511975981.017.

Mosel, Ulrike (2012). Morphosyntactic analysis in the field: A guide to the guides. In Nick Thieberger (ed.), The Oxford Handbook of Linguistic Fieldwork. Oxford: Oxford University Press, 72-89.

Mosel, Ulrike (2014). Corpus linguistic and documentary approaches in writing a grammar of a previously undescribed language. In Toshihide Nakayama and Karen Rice (eds), Practical and Methodological Issues in Grammar Writing (Language Documentation and Conversation. Special Publication No. 8). Honolulu: University of Hawai i at Manoa, 135-57. Available at: hdl.handle. net/10125/4589.

Mosel, Ulrike (2015). Searches with Regular Expressions in ELAN Corpora. 13 July. Available at: tla.mpi.nl/wp-content/uploads/2011/12/Searches in ELAN with regular expressions.pdf.

Mosel, Ulrike (2018). Corpus compilation and exploitation in language documentation projects. In Kenneth Rehg and Lyle Campbell (eds), The Oxford Handbook of Endangered Languages. Oxford: Oxford University Press, 248-70. doi.org/10.1093/oxfordhb/9780190610029.013.14.

Mosel, Ulrike. (2019). A multifunctional Teop-English dictionary. Dictionaria 4: 1-6488. Available at: dictionaria.clld.org/contributions/teop. doi.org/10.5281/ zenodo. 3257580 .

Mosel, Ulrike, Enoch Horai Magum, Jubilie Kamai, Joyce Maion, Naphtali Maion, Siimaa Ruth Rigamu, Ruth Saovana Spriggs and Yvonne Thiesen (2007). The Teop Language Corpus. Available at: dobes.mpi.nl/projects/teop/. 
Rehg, Kenneth L. (2018). Compiling dictionaries of endangered languages. In Kenneth Rehg and Lyle Campbell (eds), The Oxford Handbook of Endangered Languages. Oxford, New York: Oxford University Press, 303-26. doi.org/10.1093/oxfordhb/9780190610029.013.16.

Wierzbicka, Anna (2014). Imprisoned in English: The Hazards of English as a Default Language. New York: Oxford University Press. 
This text is taken from Meaning, Life and Culture: In conversation with Anna Wierzbicka, edited by Helen Bromhead and Zhengdao Ye, published 2020 by ANU Press, The Australian National University,

Canberra, Australia.

doi.org/10.22459/MLC.2020.19 